\title{
Radiological Study on the Osteogenesis of the Dromedary Skull (Camelus dromedaries)
}

\author{
A.S. Saber ${ }^{1}$, M.M. Abd-Elnaeim ${ }^{2}$ and K.M. Shoghy ${ }^{2}$ \\ ${ }^{1}$ Faculty of Veterinary Medicine, University of Sadat City. \\ ${ }^{2}$ Faculty of Veterinary Medicine, Assiut University.
}

With 10 figures and 3 tables $\quad$ Received March, accepted for publication April 2020

\section{Abstract}

This work was carried out with the aim of studying the osteogenesis of the skull bones in the one-humped camel fetuses. A total of 26 fetuses were used. The fetuses $\mathrm{CRL}$, ranged from $6.5-100 \mathrm{~cm}$ long. After silver nitrate impregnation for some skulls, all the specimens were examined radiologically using latero-medial, and dorso-ventral projections. The study concluded that: (I) The facial bones develop mostly from one center of ossification while the cranial ones develop from more than one center. (2) Osteogenesis of the skull bones of the camel follows in general that of the other domestic animals. (3) An ossification center for the Os interparietale could not be detected in the examined fetuses. It is also absent in the adult camel skulls. (4) The cranial bones of the one-humped camel showed a high degree of ossification at birth, like that of small ruminants.

Keywords: Ossification centers Skeleton - Skull - Dromedary camel.

\section{Introduction}

The earliest accounts including the morphological description of camel osteology were published by Lesbrè (1903), Neumani (1911), Jamdar (1960), Kanan (1961) and recently by Semieka et al. (2003), Shahid and Kausar (2005) and Yahaya et al. (2014). Histological studies on the ossification centers of the neurocranium in the camel skull were also carried out by Kanan (1960). Recently radiological studies on the skulls, the ossification centers of the camel thoracic and pelvic limbs, the development of the teeth as well as determination of the Crown-Vertebral-Rump (CVR) length in the camel fetuses were published by Ahmed et al. (1985), Saber (1990), Saber et al. (1994), and Saber and Schenk-Saber (1995) respectively.

In the absence of published reports on the axial skeleton development of the dromedary, a plane covering the prenatal period of life was suggested to be done using radiography to study the osteogenesis of the fetal camel skull, concerning their identification in 
different fetal ages (CRL), and in a chronological manner.

\section{Material and Methods}

A total of 26 camel fetuses of both sexes were considered. The fetuses were collected from Cairo Slaughterhouse. They were of different CrownVertebral-Rump-Lengt (CVRL), ranging from $6.5-100 \mathrm{~cm}$. i.e. $(6.5,8.5$, $9.5,10.5,12.5,13.0,14.5,15.0,18.0$, $19.0,21.0,22.0,26.5,27.3,28.0$, $29.5,30.0,30.5,33.0,34.0,35.0$, $36.5,46.0,52.5,76.0,100.0)$. The gestational stages were estimated based on crown vertebral rump CVR length (El-Wishy et al., 1981).

The CVRL of the fetuses considered varied between $12.5-75 \mathrm{~cm}$. In this period of development, most of the ossification loci are clearly visible in the radiographs.

Skull specimens of fetuses with CVRL ranging between 9-25 cm were treated with $95 \%$ alcohol solution for 3 days and, then after, in an aqueous solution of $0.5 \%$ silver nitrate for 3 days (Boyd and Hart, 1980).

Radiographic examination of the skulls was performed, and lateromedial and dorso-ventral views were considered (McCallum et al. 1970; Boyd and Hart, 1980; and Saber et al. 1994).

The exposure values ranged from 36 $\mathrm{kV} / 6$ - $60 \mathrm{kV} / 12 \mathrm{mAs}$ according to the size of skulls and their degree of ossification.

\section{Results and Discussion}

It is well known that the skull bones originate from different embryonal osteogenic loci by an intramembranous and endochondral ossification (Table I).

There are three developmental periods must be considered while studying the camel skull osteogenesis: In the first period, only mesenchymal tissues are present (early membranous skull). It is expected that $x$-ray photos do not show any details in fetuses of $6.5,8.5$ and $9.5 \mathrm{~cm}$ CVRL. In the second period, chondrification of the skull base can be observed but calvarium is still membranous, (fetuses of: $12.5,13.0,14.5,15.0,18.0$, $19.0,21.0,22.0,26.5,27.3,28.0$, $29.5,30.0,33.0,34.0,35.0,36.5$, 46.0 and $52.5 \mathrm{~cm} \mathrm{CVRL).} \mathrm{In} \mathrm{the} \mathrm{third}$ period of skull development, complete mineralization of skull bone takes place.

Facial bones (splancnocranium) developed in bovines from "ectomesenchyma" of the first and the second branchial arch (tables 2, 3 after Latshaw 1991).

Both facial and flat bones of calvarium develop from an intramembranous ossification. The base and ventral wall bones of the calvarium (neurocranium) originate from an endochondral ossification preceded by a chondral matrix, which firstly develops (Soana et al. 1996). 
The radiographs of the $6.5,9.5,10.5$ $\mathrm{cm}$ CVRL-camel fetuses of this study could not detect any features rather homogenous radiopaque mass (Fig I). However, the histologic study performed by Kanan (1960) on 4.3, 5.4 and $8 \mathrm{~cm}$ camel fetuses proved earlier formation of the straight lateral margins of the basal plate (floor of the cranium) and the absence of foramen rotundum and foramen ovale. The same study remarked the slow growth of the various commissures in the camel specially the basi vestibular, ali cochlear and the commissure connecting the lamina alaris. Kanan (1960) concluded that these commissures leave the auditory capsule without a firm basis. Moreover, the same study denoted that feeble development of the interorbital septum, like other mammals, due perhaps to inclusion of a part of it into the nasal capsule. The study also noticed the absence of the foramen internasale, which is found in the pig and the dog and the foramen epiphaniale.

In a $4 \mathrm{~cm}$ long bovine fetus, Soana et al. (1996) detected on the laterolateral radiograph the first draft of frontal, loci of lacrimal, zygomatic, maxillary, and incisive bones.

The x-ray photo of a camel fetus 8.5 $\mathrm{cm}$ CVRL, treated with silver nitrate impregnation supports the histological findings of Kanan (1960). The frontal, lacrimal, maxilla, mandibula, zygomatic process of the temporal, bulla tympanica and the vomer bones could be clearly identified (Fig $2 \mathrm{a}, \mathrm{b}$ ).
In the fetus of $12.5,13 \mathrm{~cm}$ CVRL, the latero-medial radiography of the skull showed the first radiopaque ossification loci representing the frontal, the first draft of the orbita, the maxilla and the mandible (Fig 3).

In the fetus of $26.5 \mathrm{~cm} \mathrm{CVRL}$, the latero-medial radiographs showed the development of many other osteogenic loci. Only four out of five loci forming the occipital bone were observed, the squamous part, two condyles and basioccipital bone (the tympanic portion)

In a fetus of $27.3 \mathrm{~cm} \mathrm{CVRL,} \mathrm{devel-}$ opment of the beforementioned four osteogenic loci of the occipital bone were progressed and the articulation between the occipital condyles and the dens of the first cervical vertebra (Atlas) became clearer, whereas the joint cavity became smaller (Fig 4).

The Os occipitale develops from 4 centers of ossification in the sheep and goat (Rajtova, 1976), while in the pig the Squama occipitalis develops alone from 3-4 centers (Engelmann, 1910) and in cattle from 2-4 centers (Wilhelm, 1924).

In a silver impregnated camel skull of $25.5 \mathrm{~cm}$ CVRL, more details than given by the $27.3 \mathrm{~cm}$ CVRL camel fetus could be detected. The maxilla and the nasal bones appeared slightly radiolucent. The perpendicular and horizontal parts of the rami of the mandible as well as the frontal and lacrimal bones and the zygomatic arch as well were fairly mineralized (Fig $5 a, b)$. 
In the sheep and goat, the zygomatic arch is completed with its processus zygomaticus of the Os temporale and the processus temporale of the Os zygomaticus at the age of 50 day of intrauterine life (Rajtova, 1976).

In fetuses of $35.0-36.5 \mathrm{~cm}$ CVRL the same features of younger fetuses were observed. A normal increase in thickness and size of skull bones similar to fetal growth was present. This was clearly observed in the loci of the occipital bone and the more radiolucent contour of the frontal and parietal bones. A radiopaque point demarcating the parietal-occipital articulation as well as the parietalfrontal articulation were easily recognized in the latero-medial view (Fig 6). In a dorso-ventral view, in addition, the lines of the bulla tympanica could be also traced (Fig 7).

Shoghy and saber (2015), in 33.5 $37 \mathrm{~cm}$ CVRL camel fetuses, described seven ossification centers to the occipital bone. Two for the lateral part i.e. two condyles (exo-occipitals), two for the basi-occipital part and three for the squamous part (one center for the parietal or dorsal part of the squamus and double centers for the supra-occipital or nuchal part of the squamus).

The same authors and in the same CVRL camel fetuses, mentioned six separate ossification centers for the sphenoid bone. one for the basiJ. Vet. Anat. sphenoid body, one for the presphenoid body, two for the both wings of the basi-sphenoid and two for the both wings of the pre-sphenoid.

In a radiograph of a camel fetus skull (52.3 cm CVRL), in a latero-medial view, a progressive development of the bulla tympanica as a circumscribed structure is clearly obvious. The processus coronoideus could be identified at this stage of development. The incisors, canine as well as the three deciduous premolar teeth were visible in the alveolar border of the mandible. The two developing maxillary premolars were also visible along the alveolar process of the maxilla (Fig 8).

A detailed study on the development of the dromedary fetuses' teeth was described in an earlier work by Saber and Schenk-Saber (1995).

In a fetal horse skull 4 months old (120 days) deciduous maxillary premolars and to a lesser extent two incisors in the alveolar arch of the mandible could be recognized by Soana et al. (1993). In the fetal bovine skull of 130 days old two developing premolar teeth were seen although the alveolar process of the maxilla was not clearly visible (Soana et al. 1996).

The maxilla and mandible were quite visible, although they appeared slightly radioleucent and poorly mineralized. 
In older camel fetuses $(76.0 \mathrm{~cm}$ CVRL) a moderate degree of mineralization of both the neurocranium and splanchnocranium of the camel skull could be assured by the clear radioleucent contour of the skull on a latero-medial radiograph (Fig 9). Rostrally the incisive bone as well as the turbinate bones could be seen, each of which originated from one single ossification locus. In spite of development of other facial bones, nasal turbinates originated from a cartilagenous center which derives from the olfactory capsule of the embryo (Barone 1974). Schink (cited by Vogler, 1926) reported in sheep and pig an extra ossification center for palatine process of the incisive bone. This finding is not recorded in the sheep and goat by Rajtova (1976) or in the camel in this study.

Close to the temporal bone the petrous and tympanic portion which will form the middle and inner ear were more prominent and were constituted of irregular bony cavities delaminated by bony septa. The Tympanic bulla image was wider.

Soana et al. (1993) identified the ethmoidal turbinate bone first in a fetal horse skull of four months old, where Soana et al. (1996) recorded them for the first time in a fetal bovine skull of 130 days old. The beforementioned authors agreed on the one single ossification locus for each of the turbinate bones, like the case in camel (Fig. 10).

J. Vet. Anat.
Hodges (1953) described the order of appearance of the ossification centers in the pig as: Mandible (the first bone to ossify), pre-maxilla, frontal and zygomatic, maxilla, parietal, nasal, lacrimal, occipital condyle and zygomatic process of the temporal, tympanic portion of the temporal, basilar part of the occiput, squamosa of the occiput, lesser wing of the sphenoid, greater wing of the sphenoid and squamosa of the hyoid, the petrous portion of the temporal.

In the camel the Os interparietal is not found (Neumani, 1911; Simon, $1965)$ and is completely fused to the squamous part of the occipital bone (Smuts and Bezuidenhaut,1987)

i.e. the squama occipitalis is a compound structure like in man (Gupp, 1966), also other primates, the perissodactyl and some carnivores (Weber, 1927), in cattle Wilhelm (1924), and in sheep (Claus, 1911; May, 1954).

In the domestic buffalo the ossa interparietale which develops from one pair of centers of ossification unite with the parietals during the last 2-3 months of gestation (Petkoff, 1935). On the contrary Rajtova (1976) who studied the skull development in goat and sheep reported that the interparietal, which mostly develops from paired anlagen, unites with the parietal during the first two months after birth. 
In the skull of fellow deer fetus of 13 weeks gestational age, Rörig (1904, 1905) did not find an interparietal and this finding is supported recently by Pohlmeyer (1985) in the same species. However, Kierdorf and Kierdorf (1992) proved the presence of Os interparietale located between the parietals and the supraoccipital. Moreover, in one of the 14 cervid skull (roe deer) examined, an isolated ossicle (preinterparietal) was described. They mentioned also that synostosis between parietal, Interparietal and supraoccipital was not observed.

A striking feature is the peculiar position of the hamulus of the pterygoid bone in relation to the distal (free) portion of the pterygoid process of the basisphenoid which is placed laterally to it. Both point in a caudolateral direction, with the hamulus extending a little further caudally than the other to the level of the mandibular fossa (Smuts and Bezuidenhaut 1987). The same authors emphasized also that the interparietal bone in the camel is completely fused to the squamous part of the occipital bone and is also not visible. Shahid and Kausar (2005) did not mention the interparietal in their description of the camel skull.

\section{Conclusions}

1) It is evident from the radiographic technique that previous treatment of the skulls with silver nitrate solution gave a better and unexpected re- sults concerning the evolution of ossification processes of the fetal camel skulls.

2) The facial bones develop mostly from one center of ossification while the cranial ones develop from more than one center (in agreement with Rajtova, 1976) in sheep and goat.

3) Osteogenesis of the skull bones of the camel fetuses follows in general that of the other domestic animals i. e. bovines, ovines, caprines, equines and swines (Evans and sack 1973. Barone 1974; Rajtova 1976; Hertsch and Girmmelmann 1979; Pilone 1982; Latshaw 1987; Nickel et al.1992).

4) An ossification center for the Os interparietale could not be detected in the examined fetuses. It is also absent in the adult camels (in agreement with Neumani 1911; Simon 1965 and Smuts and Bezudenhaut 1987).

5) The cranial bones of the onehumped camel, showed a high degree of ossification at birth, like that of small ruminants (Rajtova 1976)

\section{References}

Ahmed, A. S., Shokry, M. and ElKeiey, M. (1985): Paranasal sinuses radiological-anatomical study. Z Zbl. 
Vet. Med. C. Anat. Histol. Embryol. 14, 221-225. Barone, R. (1974): In: Anatomia Comparata degli Animali Domestici. I, 53-200 (R. Bortolami, ed.) Bologna. Edagricole.

Boyd, J. S. and Hart, G. (1980): Skull Radiographs: Silver impregnation as an interpretation aid. Veterinary Radiology, Vol. 21, 2: 82-84

Claus, T. (1911): Untersuchungen über die Entwickelung des Supraoccipitale und Interparietale beim Schaf Anat. Anz. 39: 364-374.

El-Wishy, A. B., Hemeida, N. A., Omar, M. A., Mobarak, A. M., ElSayed, M. A. (1981): Functional changes in the pregnant camel with special reference to foetal growth. $\mathrm{Br}$ Vet J, 37:527-53.

Engelmann,T. (1910): Beitrag Zur Kenntnis der Entwicklungsgeschichte der Hinterhauptschuppe beim Schwein, Inaug. Diss. Zürich. (cited by Rajtova, 1976).

Evans, H. E. and Sack, W. O. (1973): Prenatal development of domestic and laboratory mammals: growth curves, external features and selected references. Anat. Histol. Embryol. 2, I I.

Hertsch, B. and Girmmelmann, E. (1979): Röntgenologische Untersuchung der Ossifikations-vorgänge am widerrist beim pferd. Zbl. Vet. Med. A, 26, 191.

J. Vet. Anat.
Gupp, E. (1966): Die Entwickelung des Kopfskelettes in: O. Hertwig (ed.) Handbuch der vergleichenden und experimentellen Entwickelungslehre der Wirbeltiere, Bd.3, Teil 2, pp. 573584, G. Fischer, Jena.

Hodges, J. R. (1953): Ossification in the fetal pig- A radiographic study. Anat. Rec. 116, 315325.

Jamdar, M. N. (1960): Comparative anatomy of the bony system of the camel (Camelus dromedarius). (III) Axial skeleton. Indian Vet. J. 38, 5364.

Kanan, C. V. (1960): Notes on the vertebral column, ribs and sternum of the camel. Sudan J.Vet. Sci. 1, 8491.

Kierdorf, U. and Kierdorf, H. (1992): Studies on the parietal region of the Cervid skull I. Remarkes on the Os interparietale in the skull of the Roe deer (Capreolus capreolus L.). Anat. Histol. Embryol. 21: 112-117.

Latshaw, W. K. (1987): Lo sviluppo degli animali domestici. Embriologia ad orientamento clinico. Ed. It. Canavese, B., Ferrandi, B., Casa Ed. Ambrosiana, Milano (Cited by Soana et al. 1993).

Lesbré, M. F. (1903): Recherches anatomiques sur les camélidés. Arch. Museum hist., nat, Lyon 8: 1-196.

Mac Callum, F. J., Latshaw, W. K. and Kelly, R. E. (1970): Identification 
of postnatal ossification sites: A contribution to radiographic interpretation. Br. Vet. J. 127: 83.

May, N. D. S. (1954): The anatomy of the sheep. $2^{\text {nd. }}$ ed. Queensland.

Neumanie, A. (1911): The comparative osteology of the camel; Part I. Printing press journal Al-Garidah, Cairo.

Nickel, R., Schummer, A. and Seiferle, E. (1992): Lehrbuch der Anatomie der Haustiere, Band I. Bewegungsapparat. Verlag Paul Parey. Berlin und Hamburg.

Pilone, A. (1982): Identificazione delle sedi di ossificazione del cranio die feti bovini. Acta Med. Vet. 28, 249.

Petkoff, A. (1935): Über die Parietalgegend beim Hausbüffel. Anat. Anz. 80: 17-24.

Pohlmeyer, K. (1985): Our vergleichenden Anatomie von Damtier (Dama dama L. 1758), Schaf (Ovis aries L. 1758) und Ziege (Capra hircus L. 1758): Osteologie und postnatale Osteogenese. Paul Parey, Berlin und Hamburg.

Rajtova, V. (1976): Entwickelung des Skelets beim Schafund bei der Ziege IV. Osteogenesis des Graniums. Gegenb.morph. Jahrb. 122: 927-940.
Rörig, A. (1904): Das Wachstum des Schädels von Capreolus vulgaris, Cervus elaphus und Dama vulgaris. Bibliotheca medica Abt. A., Heft 4, E. Nägele, Stuttgart.

Rörig, A. (1905): Das Wachstum des Schädels von Capreolus vulgaris, Cervus elaphus und Dama vulgaris Ant. Anz. 26: 17-25.

Saber, A. S. (1990): Radiographic anatomy of the dromedary skull. Vet. Rad. Vol. 31, No 3.161-164.

Saber, A. S., Abdel-Monim, M. E. and Allam El-Din, M. A. (1994): Radiographic study of the teeth development in fetal dromedary. JCPR, June: 34-38.

Saber, A. S. and Schenk-Saber, B. (1995): Radiographic determination of CVR length in the camel fetus (Camelus dromedarius). JCPR. December: 101-104.

Semieka, M.A., Ahmed, A.F. and Misk, N.A. (2003): Radiographic studies on the mandible of buffaloes and camels with special reference to mandibulo-alveolar nerve block. Journal of Camel Practice and Research 10 (1):9-16

Shahid, R.U. and Kausar, R. (2005): Comparative Gross Anatomical Studies of the Skull of One-humped Camel (Camelus dromedaries) Pakistan Vet. J., 25(4) 205: Short communication. 
Shoghy, K.M. and Saber, A.S. (2015): Development of Central Skull Base of the One Humped Camel (Camelus dromedarius): Dissection, $\mathrm{CT}, \mathrm{MRI}$ and Plain Radiography of Ossification Centers. J Vet Anat Vol. 8, No. 2, (2015) 1 - 16

Simon, E. (1965): Endocranium, Endokranialousguss und Gehrin beim Einhöckerigen kamel (Camelus dromedarius) Acta Anat. 60, 122-151.

Smuts, M. M. S., and Bezuidenhaut, A. J. (1987): Anatomy of the dromedary. Clarendon press. Oxford.

Soana, S., Bertoni, G. Corradi, A., Cnudi, G. and Botti, P. (1993): Osteogenese des Schädels beim Pferdfötus. Pferdheilkunde 9, I: 27-34.

Soana, S., Bertoni, G., and Botti, P. (1996): Osteogenesis of the fetal bovine skull. Anat. Histol. Embryol. 25, 167-173.

\section{Author Address:}

Prof. Dr. A.S. Saber

Fac. Vet. Med., Uni. Of Sadat City, EGYPT

saberashraf_2@yahoo.com
Yahaya, A., Olopade, J.O., and Kwari, H.D. (2014): Anatomical Study of the Variations of the Facial bones in Skull of the Camel (Camelus dromendarius) in Nigeria. Nigerian Veterinary Journal, Vol. 35(3) 1053-1959

Vogler, A. (1926): Intrauterine Verknöcherung der Ossa faciei des Schweines. Gegenbaurs morphol. Jahrb. 55: 568-606.

Weber, M. (1927): Die Säugetiere, Bd. 1, $2^{\text {nd }}$ ed. G. Fisher, Jena.

Wilhelm, J. (1924): Zur Entwickelungsgeschichte der Hinterhauptsschuppe des Rindes. Anat. Anz. 59: I-1 1. 
Table (1). Osteogenesis of the skull bones: Endochondral and intramembranous ossification. Number of embryonal osteogenic loci.

Compiled from Barone (1974), Raitova (1976) and Soana et al. (1996).

\begin{tabular}{|c|c|c|}
\hline \multirow[t]{2}{*}{ Bones } & Type of ossification & \multirow{2}{*}{$\begin{array}{l}\text { No. of ossification } \\
\text { centers }\end{array}$} \\
\hline & $\begin{array}{c}\text { Chondral Membranous } \\
\text { squamosa }\end{array}$ & \\
\hline \multicolumn{3}{|l|}{ Neurocranium } \\
\hline$\overline{\text { Os occipitale }}$ & +++ & $4-5$ \\
\hline $\begin{array}{l}\text { Os sphenoidale } \\
\text { presphenoidale } \\
\text { basisphenoidale }\end{array}$ & +++ & $\begin{array}{c}4 \\
\text { (2) } 4 \\
\text { (2) } 6\end{array}$ \\
\hline $\begin{array}{l}\text { Os ethmoidale: } \\
\text { ethmoturbinate }\end{array}$ & +++ & 6 \\
\hline Os parietale & +++ & 1 \\
\hline Os interparietale & +++ & 1 \\
\hline Os frontale & & Multiple foci (up 7) \\
\hline $\begin{array}{l}\text { Os temporale: pars pe- } \\
\text { trosa }\end{array}$ & +++ & 1 \\
\hline \multicolumn{3}{|l|}{ Splancnocranium } \\
\hline Os nasale: conchae & +++ & 1 \\
\hline Os lacrimale & +++ & $1+7$ \\
\hline Maxilla & +++ & $1+3$ \\
\hline Os incisivum & & 1 \\
\hline Os orbitosphenoidale & +++ & \\
\hline Os pterygoideum & +++ & 1 \\
\hline Os zygomaticum & +++ & $1+2$ additonal loci \\
\hline Os palatinum & +++ & 1+ additonal loci \\
\hline Vomer & +++ & 1 \\
\hline Incus & +++ & \\
\hline Malleus & +++ & \\
\hline Stapes & +++ & \\
\hline Bulla tympanica & +++ & \\
\hline Mandibula & +++ & \\
\hline Os hyoideus & & 4 \\
\hline Turbinate bone & & 2 \\
\hline
\end{tabular}


Table (2). Development of the facial bones from first and second branchial arch and from fronto-mesenchymal processes (after Latshaw 1991).

\begin{tabular}{|lll|}
\hline \multicolumn{1}{|c|}{ Origin } & $\begin{array}{ll}\text { Facial bone structures } \\
\text { Ectomesenchymal }\end{array}$ & $\begin{array}{c}\text { Mesenchymal } \\
\text { (fronto-nasal pro- } \\
\text { cesses) }\end{array}$ \\
\hline & $\begin{array}{l}\text { Mandibula Maxilla } \\
\text { Incus-Malleus }\end{array}$ & \\
& $\begin{array}{l}\text { Pterygoideous processes } \\
\text { Palatine bone }\end{array}$ & $\begin{array}{l}\text { Frontal processes } \\
\text { Lateral nasal pro- } \\
\text { cesses }\end{array}$ \\
& $\begin{array}{l}\text { Squama temporal bone } \\
\text { Zygomatic bone }\end{array}$ & $\begin{array}{l}\text { Medial nasal pro- } \\
\text { cesses }\end{array}$ \\
& Stapse & $\begin{array}{l}\text { Maxillary pro- } \\
\text { cesses }\end{array}$ \\
& Temporal portion of bulla & Mandibular pro- \\
tympanica & cesses \\
Branchial arch (mandibu- & A portion of hyoideus appa- \\
rar) membranous bone & ratus & \\
II. Branchial arch & & \\
(hyoideus) & & \\
\hline
\end{tabular}

Table (3). Structures which develop from the embryonal splanchnocranium (after Latshaw, 1987).

\begin{tabular}{|l|c|}
\hline Embryonal structures & Skeletal structures \\
\hline $\begin{array}{l}\text { Fronto-nasal processes } \\
\text { Lateral nasal processes } \\
\text { Medial nasal processes } \\
\text { Maxillary processes } \\
\text { Mandibular processes }\end{array}$ & $\begin{array}{c}\text { Os frontale } \\
\text { Os nasale, Os lacrimale } \\
\end{array}$ \\
& Vomer, Os incisivum \\
& Maxilla, Os palatinum, \\
Os pterygoideum, & Os zygomaticum, \\
& Pars squamosa of Os temporale \\
& Mandible \\
\hline
\end{tabular}




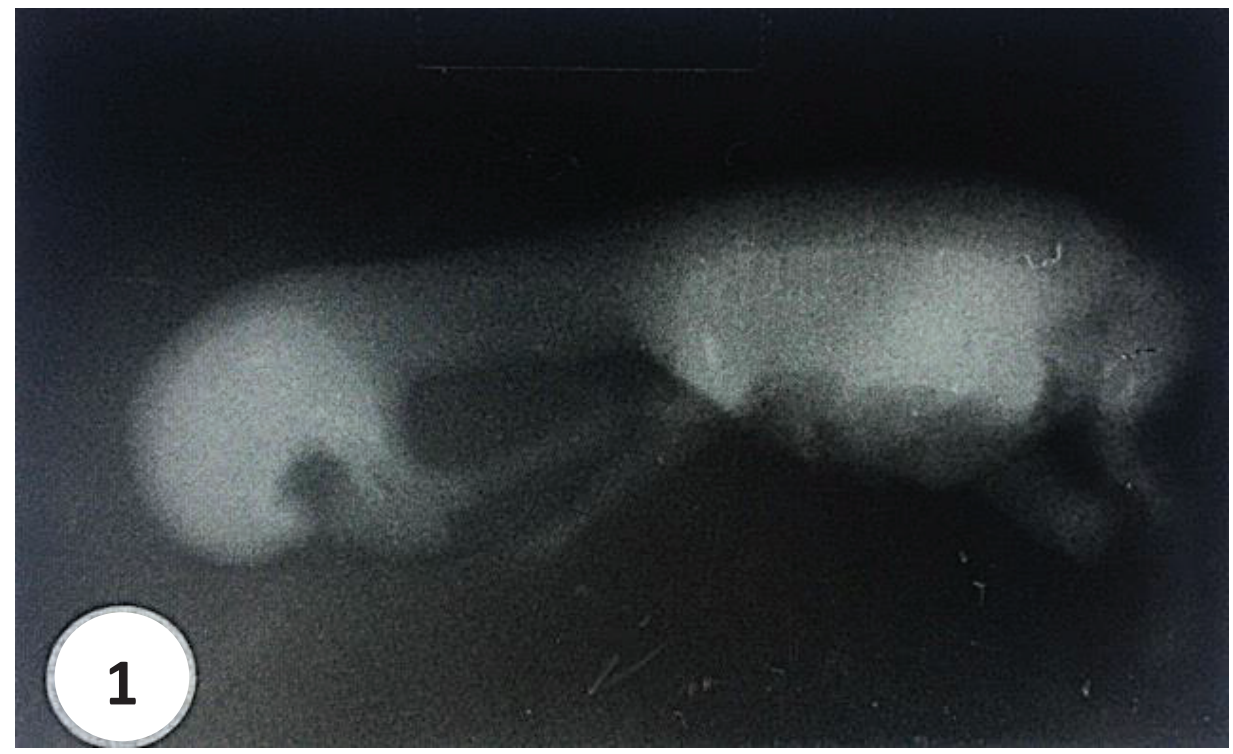

Fig (1): Radiograph of a camel fetus (9.0 cm CVRL). The skull is only identified as a homogenous radiopaque mass.

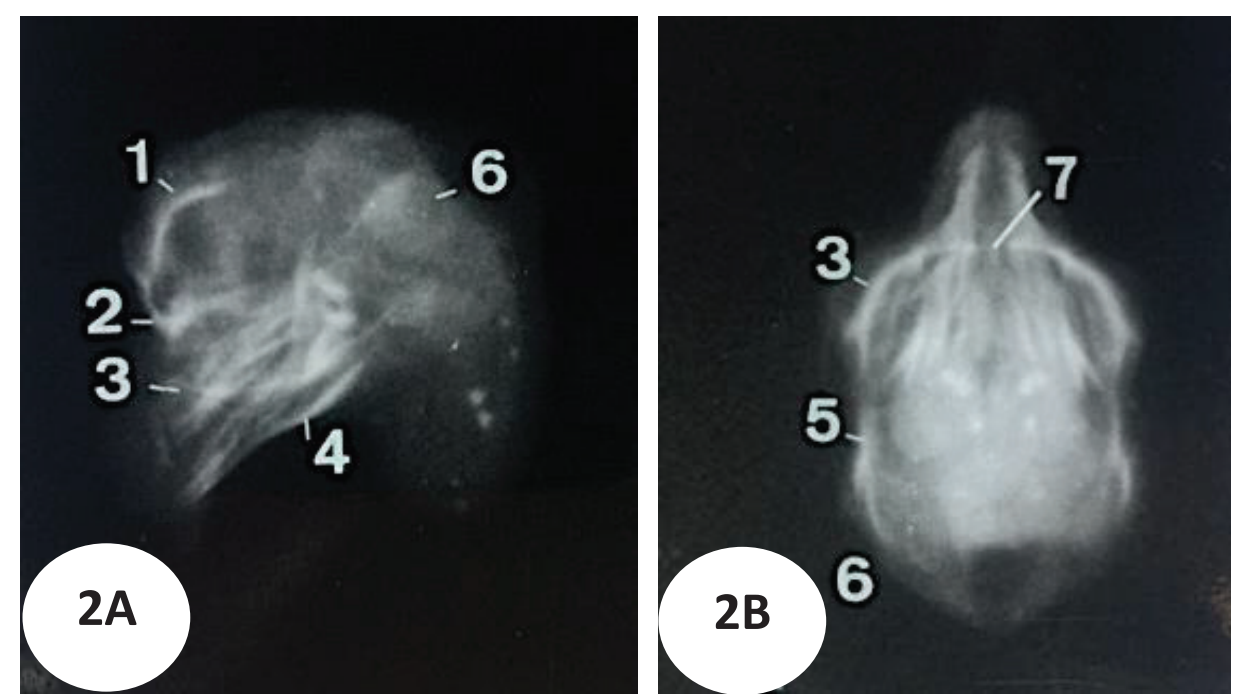

Fig (2): Radiograph of the skull of a camel fetus (8.5 cm CVRL) after silvernitrate impregnation. (A) Latero-medial view. (B) Dorso-ventral view. I Os frontale; 2 Os lacrimale; 3 Maxilla; 4 Mandibula; 5 Os temporale, processes zygomaticus; 6 Os temporale, bulla tympanica; 7 Vomer. 


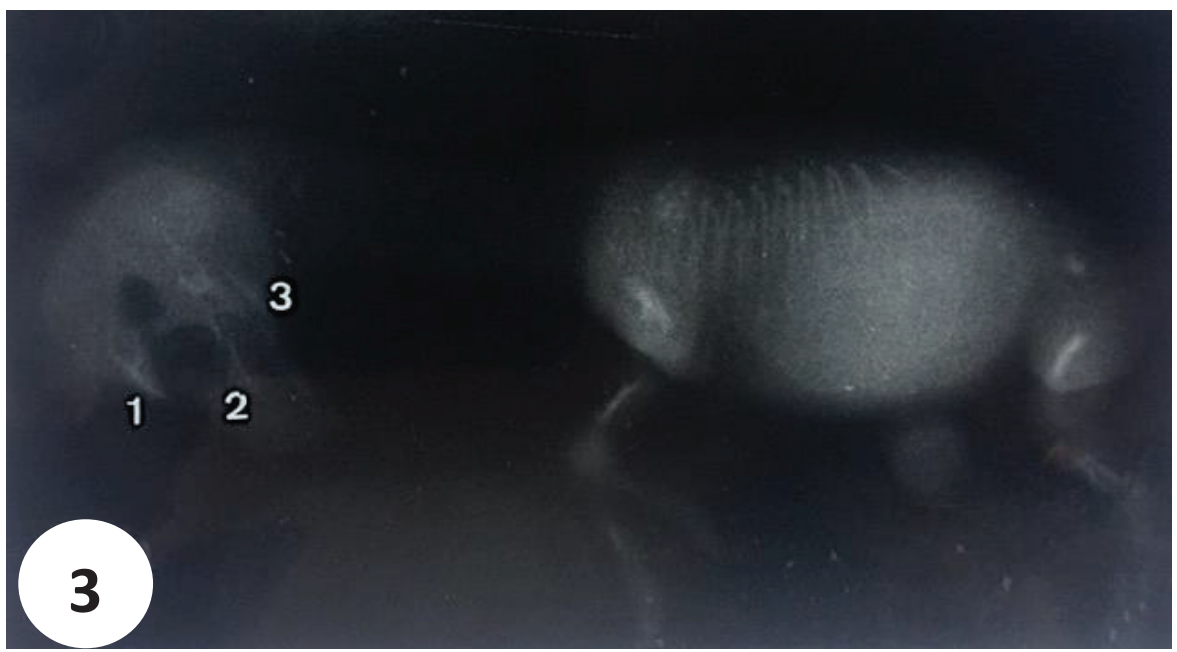

Fig (3): Radiograph of a camel fetus (13.0 cm CVRL), latero-medial projection, showing the first osteogenic loci of Os frontale (I); maxilla (2) and mandibula (3).

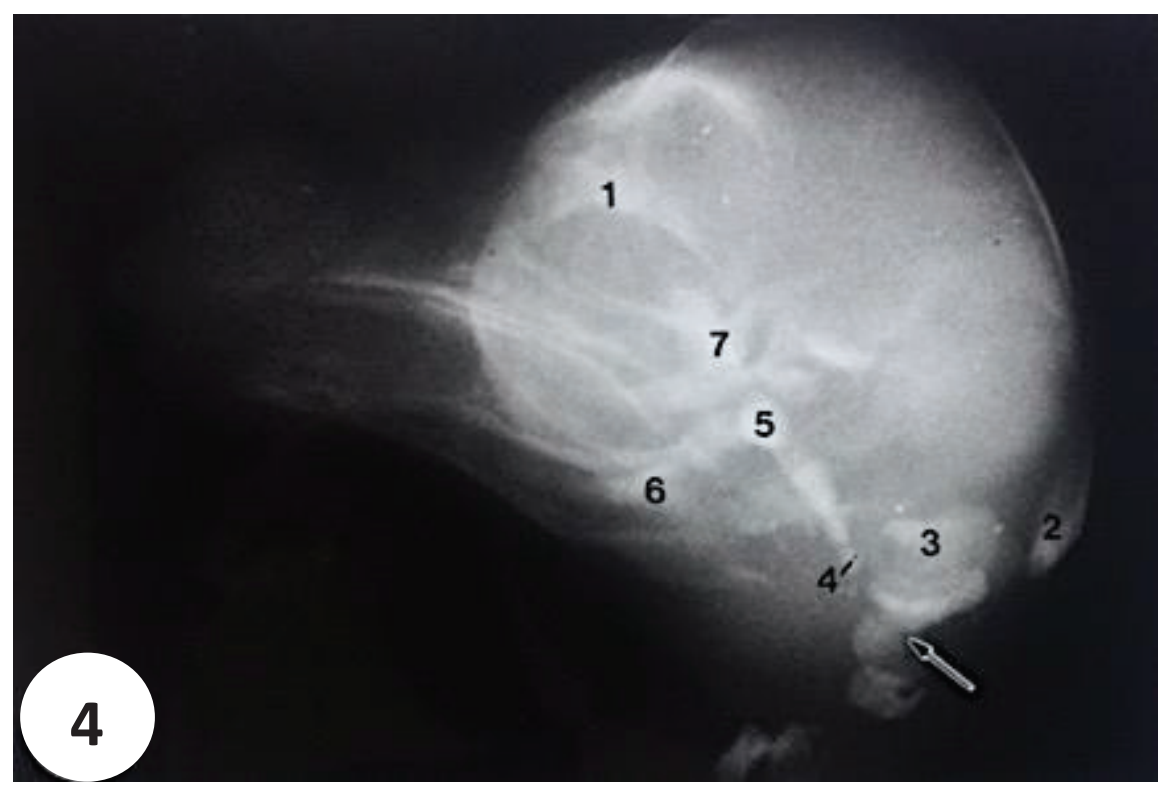

Fig (4): Radiograph of a camel fetus skull ( $27.3 \mathrm{~cm} \mathrm{CVRL),} \mathrm{latero-medial} \mathrm{pro-}$ jection, showing:

1 Os frontale; 2 Squamous occipitalis; 3 Pars lateralis of occipital with condylus occipitalis; 4 Os occipitalis, pars basalis; 5 Basisphenoid; 6 Mandibula; 7 Praesphenoid

Notice: The atlanto-occipital articulation with narrower joint cavity (arrow). 

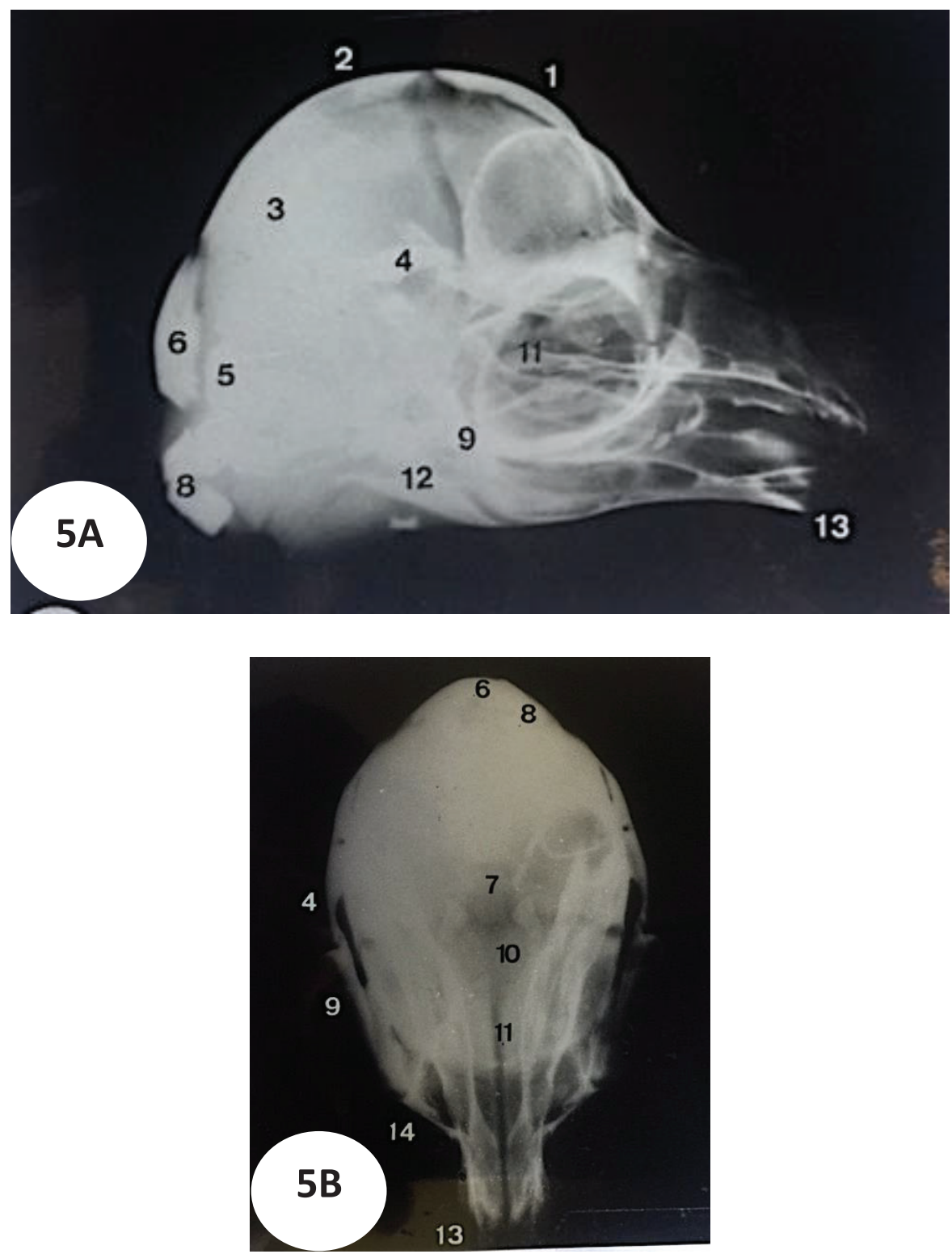

Fig (5 A, B): Radiograph of a camel fetus skull (25.5 cm CVRL). A) lateromedial projection, B) dorso-ventral projection. I Os frontale; 2 Os parietale; 3 Os temporale, pars squamosa; 4 Os temporale, processus zygomaticus; 5 Os temporale, processus mastoideus; 6 Os occipitalis, pars squamous; 7 Os occipitalis, pars basalis; 8 Os occipitalis, condylus occipitalis; 9 Os zygomaticus; 10 Os parasphenoidale; I I Vomer; 12 Mandibula; 13 Os incisivum; 14 Maxilla. 


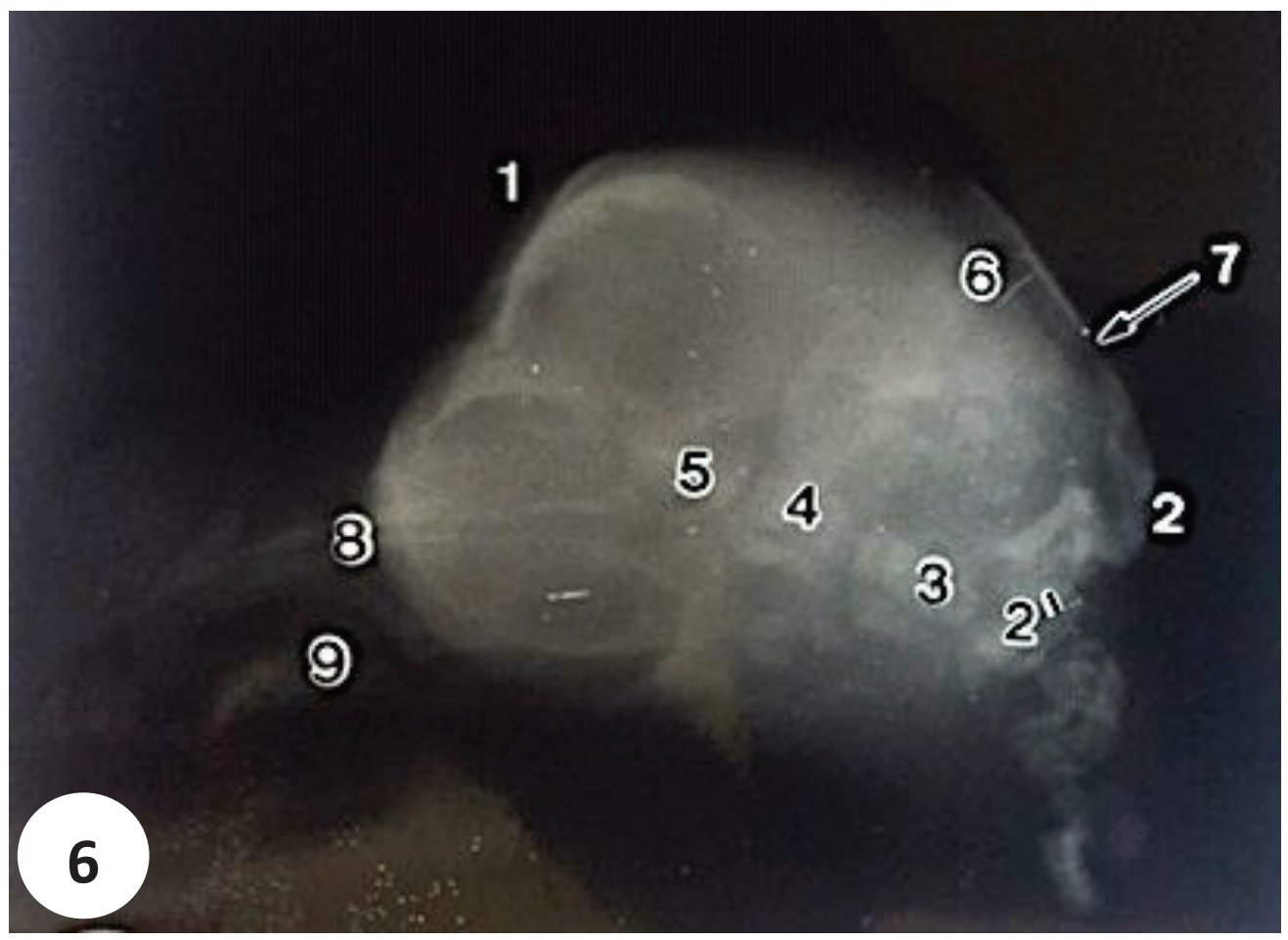

Fig (6): Radiograph of a camel fetus skull of $35.0 \mathrm{~cm}$ CVRL, latero-medial view.

I Os frontale; 2 Squamous occipitalis; 2' Condylus occipitalis; 3 Os occipitalis, pars basalis; 4 Os sphenoidale, corpus; 5 Basisphenoid; 6 Os parietale; 7 Occipitoparietal junction; 8 Maxilla; 9 Mandibula 


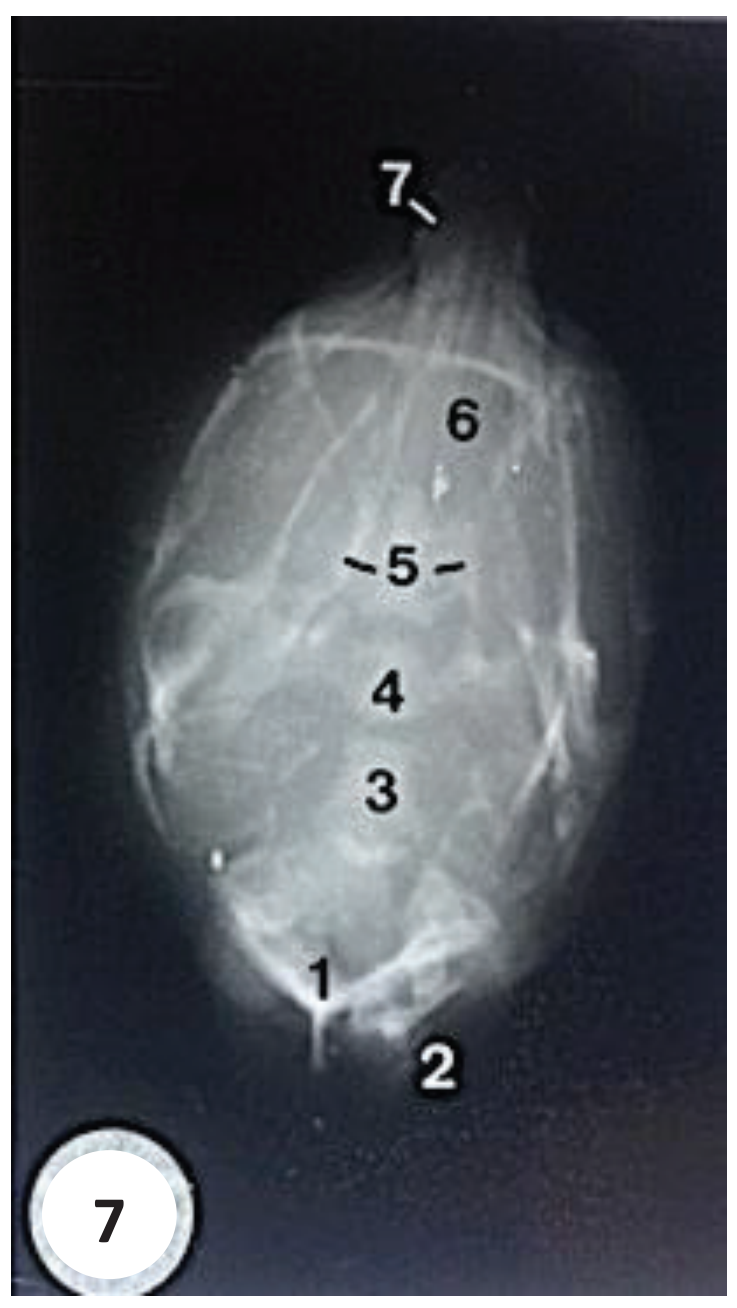

Fig (7): Radiograph of a camel fetus skull of (36.5 cm CVRL), dorso-ventral view.

I Squamous occipitalis; 2 Condylus occipitalis; 3 Os occipitalis, pars basalis; 4 Os sphenoid, corpus; 5 Os sphenoidale, processus pterygoideus; 6 Vomer; 7 Corpus ossis incisivi. 


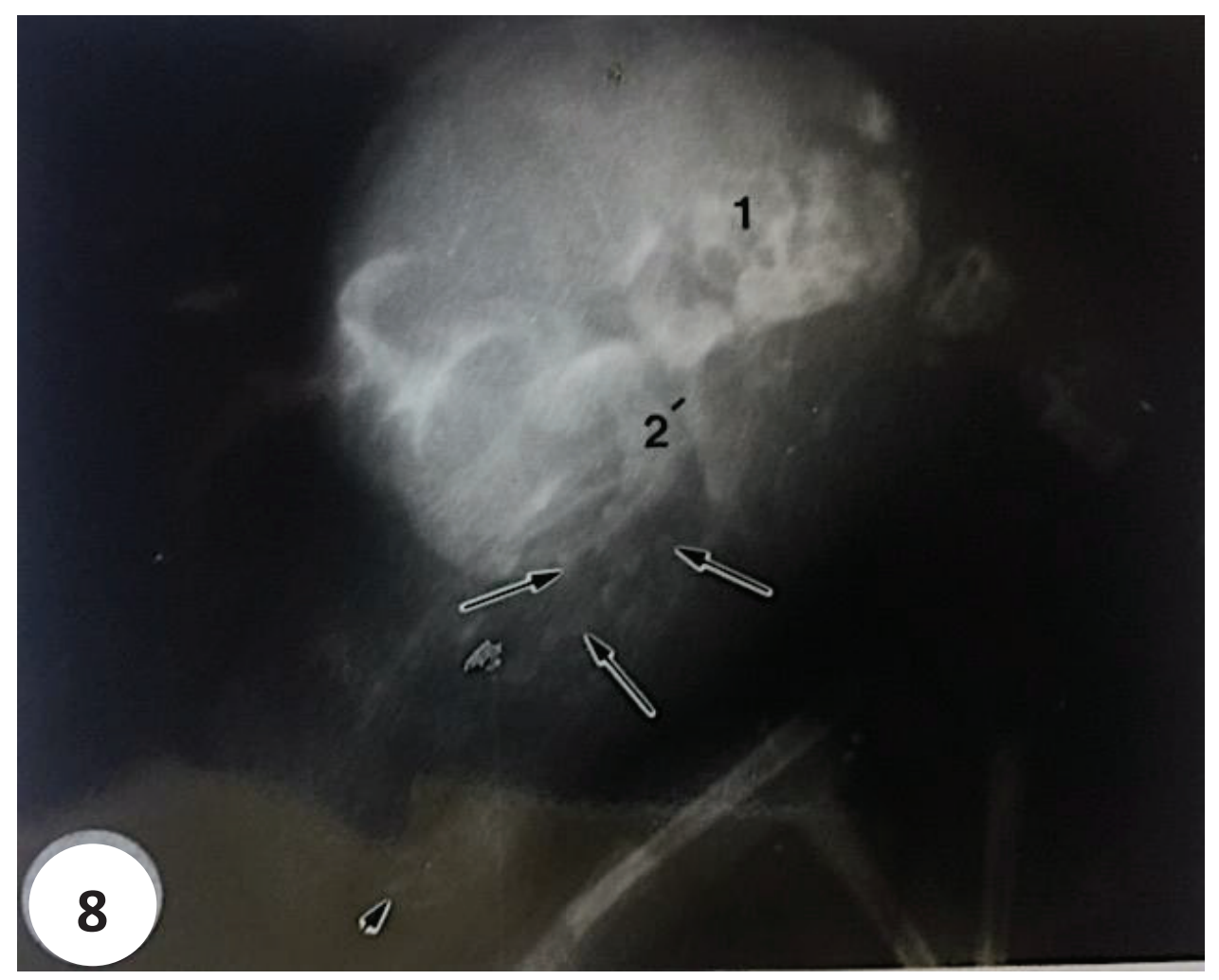

Fig (8): Radiograph of a camel fetus skull of (52.3 cm CVRL), latero-medial projection, showing the more circumscribed bulla tympanica (I). The coronoid process of the mandible is also visible (2) as well as mandibular incisors (arrow head), the deciduous premolars on both the maxilla and mandible (arrows). 


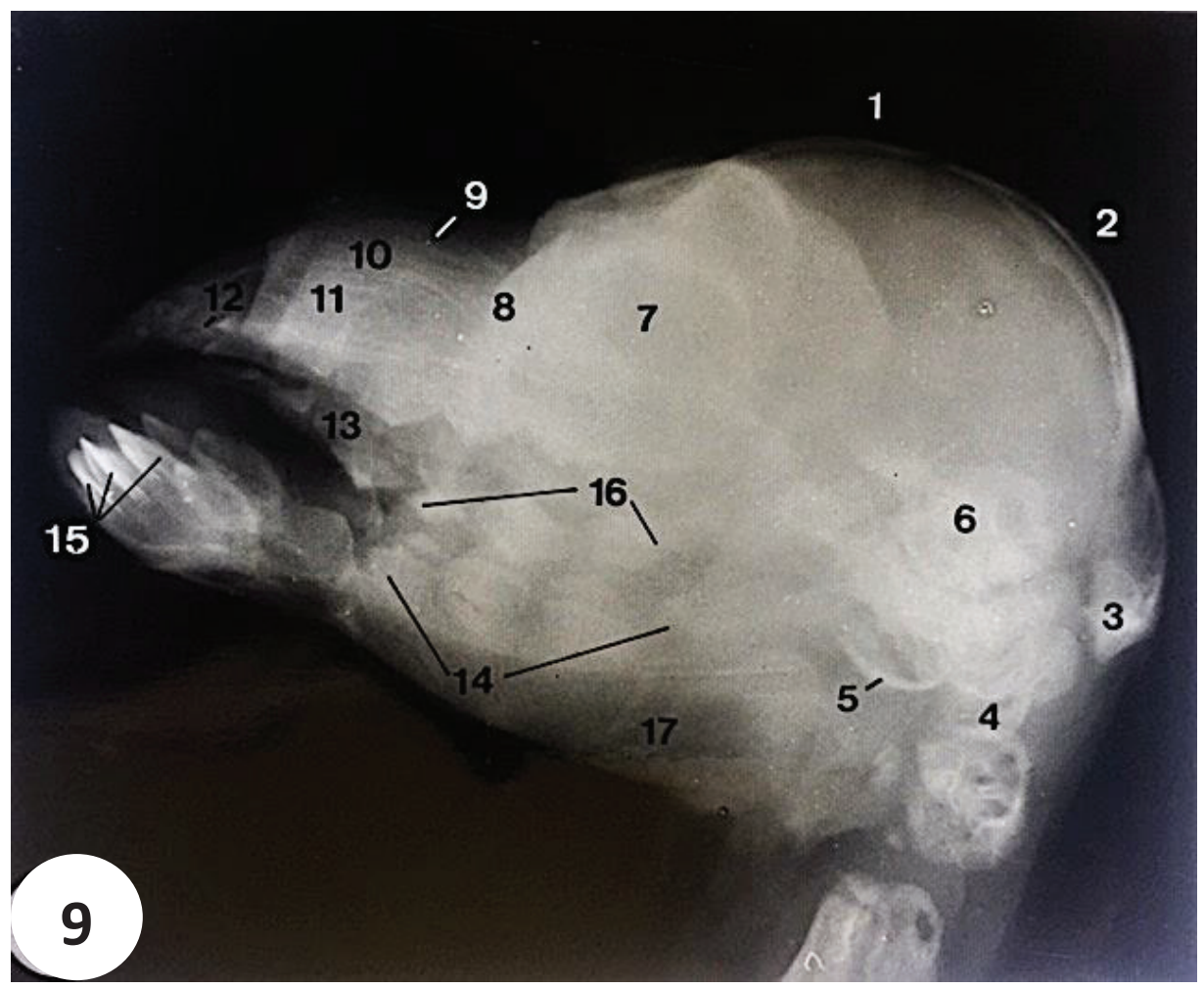

Fig (9): Radiograph of a camel fetus skull of (76.0 cm CVRL),

I Os frontale; 2 Os parietale; 3 Squama occipitalis; 4 condylus occipitalis; 5 Os temporale; 6 Bulla tympanica; 7 Orbita; 8 Ethmoturbinalie; 9 Os nasale; 10 Os nasale, concha nasalis dorsalis; 11 Os nasale, concha nasalis ventralis; 12 Os incisivum; 13 Processus palatinus maxillae; 14 Mandibulare dents premolars decidui; 15 Mandibulare dents incisivi; 16 Maxillare dents premolares decidui; 17 Mandibula. 


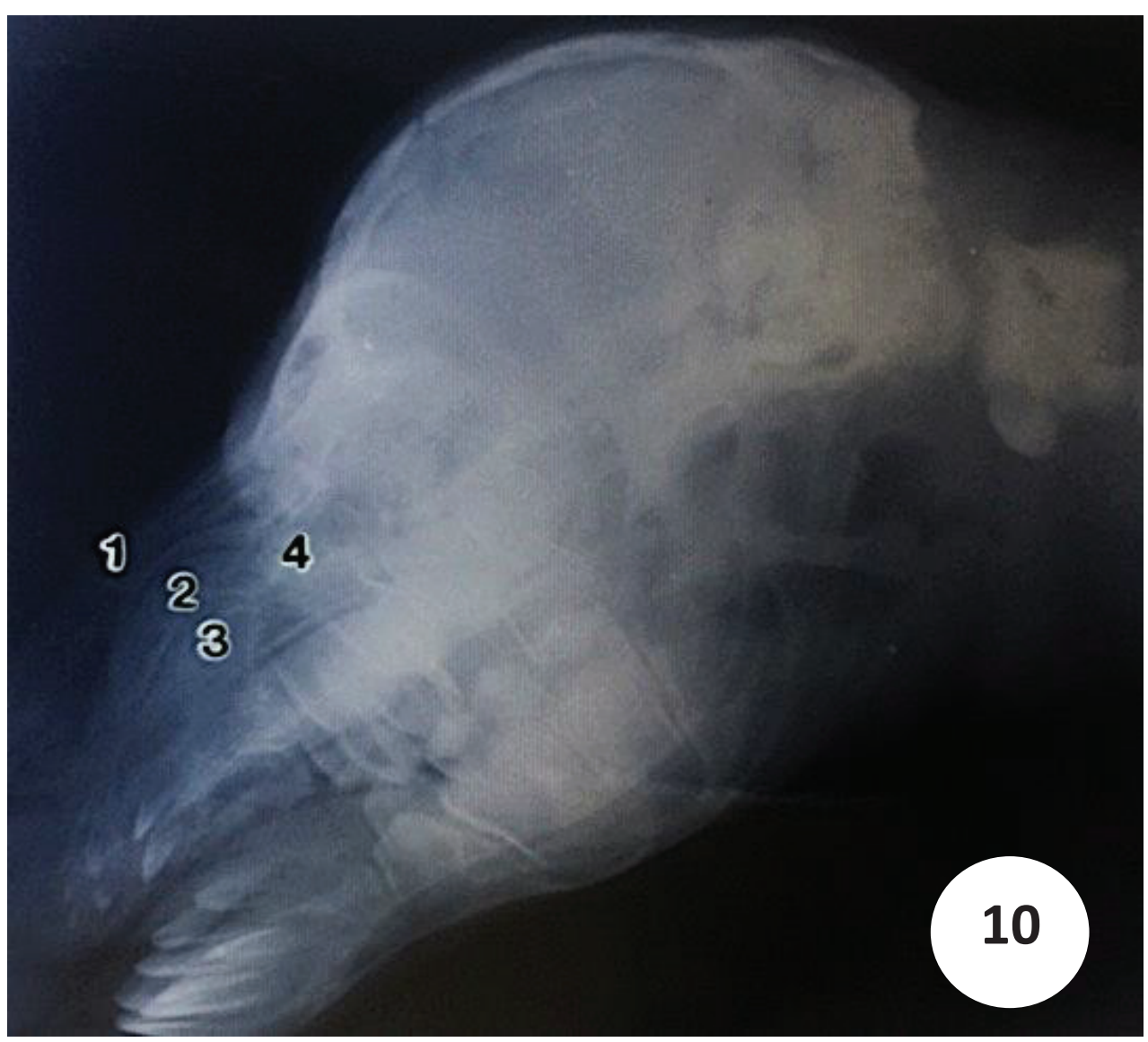

Fig (10): Radiograph of a camel fetus skull of (100 cm CVRL), I Os nasale, 2 Os nasale, concha nasalis dorsalis, 3 Os nasale, concha nasalis ventralis, 4 Ethmoturbinalia. 


\section{Animal species in this issue}

\section{One-humped came (Camelus dromedarius)}

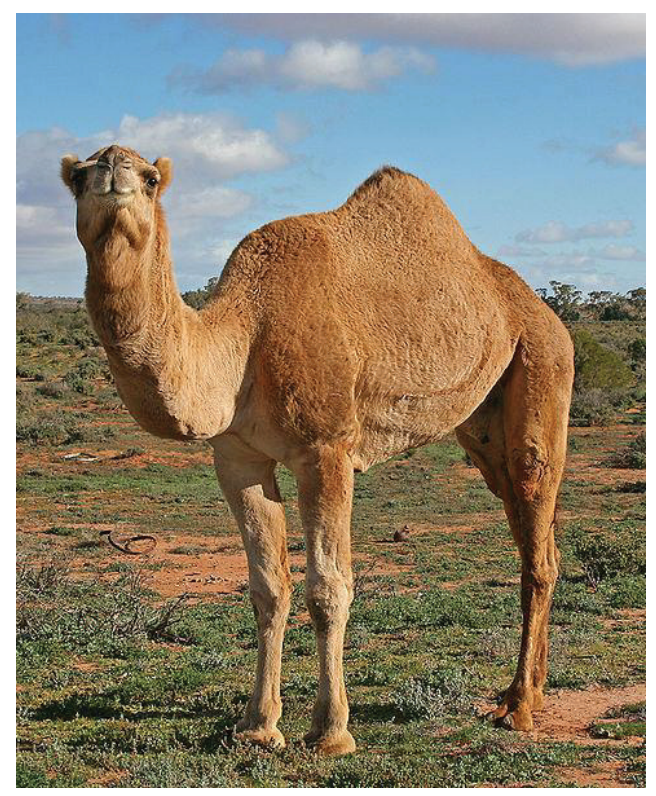

Kingdom: Animalia, Phylum: Chordata, Class: Mammalia, Oder: Artiodactyla. Family:Camelidae, Genus: Camelus

Camel is an even-toed ungulate within the genus Camelus, bearing distinctive fatty deposits known as humps on its back. There are two species of camels: the dromedary or Arabian camel has a single hump, and the Bactrian camel has two humps. They are native to the dry desert areas of West Asia, and Central and East Asia, respectively. Both species are domesticated to provide milk and meat, and as beasts of burden.

The average life expectancy of a camel is 40 to 50 years. A fully grown adult camel stands $1.85 \mathrm{~m}$ at the shoulder and $2.15 \mathrm{~m}$ at the hump. The hump rises about 30 inches $(76.20 \mathrm{~cm})$ out of its body. Camels can run at up to $65 \mathrm{~km} / \mathrm{h}(40 \mathrm{mph})$ in short bursts and sustain speeds of up to $40 \mathrm{~km} / \mathrm{h}(25 \mathrm{mph})$.

Fossil evidence indicates that the ancestors of modern camels evolved in North America during the Palaeogene period, and later spread to most parts of Asia. Humans first domesticated camels before 2000 BC.

Camels are able to withstand changes in body temperature and water content that would kill most other animals. Their temperature ranges from $34{ }^{\circ} \mathrm{C}$ at night and up to $41^{\circ} \mathrm{C}$ during the day, and only above this threshold will they begin to sweat. 